\title{
Setting Up the Local Deportation Regime
}

The city of Nashville conjures up specific "All-American" images: honky tonk bars, country music, and southern fried chicken. Miles away from downtown tourist destinations, major thoroughfares in Southeast Nashville are lined with storefronts and businesses where most transactions occur in Spanish. Small grocery stores sell tortillas and Mexican products, boasting an impressive variety of Mexican candy, chips, and cookies. Among the businesses catering to Mexican and Central American residents are panaderías (Mexican bakeries), peluquerías (hair salons), carnicerías (butcher shops), taquerías (taco shops), pupuserías (restaurants serving Salvadoran pupusas, a thick corn patty stuffed with cheese or meat), and llanterías (tire shops). On weekends, parks host men's and women's soccer leagues where teams of young Latino men and women compete with one another. Families arrive to watch the games and enjoy the snacks that vendors sell in the park: tacos, elote en vaso (corn in a cup, served with mayonnaise, cream, cheese, and salsa), paletas (popsicles), and chicharrones de harina (puffy fried wheat snacks doused in lime and hot sauce). These scenes, a visual depiction of a city in transition, have played out in cities and towns across the country but have been particularly pronounced in the South.

Between 1990 and 2000, the percentage of Mexican immigrants in the traditional destination states of California and Texas declined, and the states of Georgia, Alabama, Tennessee, Arkansas, and North Carolina emerged as new immigrant destinations. ${ }^{1}$ Indeed, eight of the ten states with the highest percentage change of the Mexican-born population between 1990 and 2000 were located in the South; in most of these states, foreign-born populations more than doubled in size. ${ }^{2}$ Nashville was no exception, experiencing a 134 percent increase in its Latino 
population between 2000 and 2010. Indeed, without the arrival of new Latino residents, the city's population would have declined in the 1990 and 200os. ${ }^{3}$ This trend continued through the 20oos, as Latino immigrant workers gave way to entire families and communities. ${ }^{4}$ By 2010 , Latinos constituted almost 10 percent of Davidson County's population, up from 4.5 percent in 2000.5

Most foreign-born Latinos in Tennessee were born in Mexico and arrived in the United States via the traditional gateway states of California, Florida, and Texas. Unemployment was low, and new residents easily found employment in construction and service industries. ${ }^{6}$ Latino immigrant residents I spoke to during the course of this fieldwork described their move to Nashville in favorable terms. For example, Alfonso, who had arrived in Nashville from Texas in 1988, explained: "I worked in Houston and San Antonio, but I came here because there was more work and also they paid higher wages, and things are cheaper here than in other states. That's why I came. I feel more comfortable in Tennessee." David, who moved to Nashville in the mid-1990s from Los Angeles, expressed similar sentiments: "Well, my brother was here, and so I sent my wife and my daughters from Los Angeles and they liked it. Then I followed, for the future of my family. It's much calmer here in Tennessee, so I like it as a place to raise my family."

In the mid-200os, the region's changing demographics became a lightning rod for political controversy. ${ }^{7}$ State and local actors passed a number of anti-immigrant bills and punitive policies directed at making life harder for the area's Latino immigrant residents. For Latino residents, this shift was tangible. Maria, a Mexican immigrant who had moved to Nashville from Los Angeles in 1994, told me that the city had changed since she arrived:

When I got here it's like, at that time we had access to a driver's license without a social security number and there were more services available. It was less difficult than now. There was a radical change. You could feel the change, there were more laws affecting us, they took away programs that benefited the undocumented community, and since then we have felt anti-immigrant sentiment more.

Jesús, a Mexican immigrant who owned a popular Mexican restaurant, attributed the backlash to immigrants' expanded visibility in the city. On March 29, 2006, thousands of Latino immigrants and their supporters marched for immigrants' rights in downtown Nashville. The Nashville march occurred in response to a proposed federal immigration law that would have criminalized undocumented immigrants by making living in the United States without authorization a felony. Immigrant advocacy networks across the United States organized against the bill, and marches for immigrant justice occurred in more than 140 cities across thirty-nine states. Building on the momentum of the marches, organizers called for a national day of boycott on May 1, 2006, and urged immigrants and their supporters to demonstrate their importance to 
the US economy by not shopping or working. Thousands of Latinos in Nashville participated in the national "Day without Immigrants" boycott, including Jesús, who closed the restaurant. However, Jesús grew to have mixed feelings about his decision to participation in the boycott, saying that he did not regret his decision but also describing it as a mistake:

We closed on the national day of boycott, we participated and I don't regret doing it, but looking back on it, I feel that it was a mistake to close the restaurants because our customers had been patronizing my businesses the whole time and it wasn't their fault. ... I think that they would have had a more favorable opinion of us if that day we had said, "Support our cause, but here we are to work for you." To deny my clients service when they had been coming every week or twice a week to eat with us ... we felt that after we closed some clients never came back. We lost clients, so I think it was a mistake to participate in that way.

Jesús believed that his patrons were willing to tolerate the immigrant community as workers who served them but not as residents who mobilized for justice and equality.

The widespread mobilization for immigrants' rights in the spring of 2006 also fueled an anti-immigrant backlash. Media coverage of the immigrant rights' movement shifted from a debate about immigration reform to the presence of unauthorized immigrants as a social problem. ${ }^{8}$ In Nashville, conservative media pundits were furious that so many Latino immigrants had marched in downtown Nashville. Speaking to a reporter, conservative radio host Phil Valentine explained how the protests had galvanized area residents: "Before the protests, [people] were sitting on the sidelines, but now they are incensed. They see that these people are carrying Mexican flags, they don't speak English - they are in your face. People are more attuned to what the problem is." Indeed, some of the anti-immigrant state and municipal laws detailed in the last chapter, including Hazleton's ordinance, emerged several months after the immigrant rights' marches.

The perceptions articulated by Latino immigrant residents in this section are testament to the region's shifting context of reception. In the sociological research on immigration, context of reception refers to the structural and cultural characteristics of specific places that affect how immigrants experience or are incorporated into those places..$^{10}$ A number of studies of Latino migration to the South have documented that the cautious optimism with which Latino immigrants were initially received was replaced by explicit hostility. ${ }^{11}$ As I detailed in the last chapter, anti-immigrant sentiment became pervasive in the South and many other destinations across the country in the mid-200os, resulting in a flurry of restrictive and punitive laws directed at unauthorized immigrants. These punitive laws change an area's context of reception.

According to political scientist Daniel Hopkins, localized anti-immigrant responses emerge in places that are undergoing sudden demographic changes at the 
same time that immigration is a nationally salient issue. ${ }^{12}$ Additional research suggests that localities with higher concentrations of Republican voters are significantly more likely to propose and pass exclusionary immigration laws than localities that trend Democratic. ${ }^{13}$ This chapter examines Nashville's changing context of reception by focusing on three policy areas that generated substantial controversy and redrew the boundaries around local membership for unauthorized immigrants: access to state driver's licenses and identification cards, Davidson County's participation in the $287(\mathrm{~g})$ immigration enforcement program, and an "English-only" ordinance that attempted to make English the Nashville government's official language. I employ the sociological literatures on citizenship and boundaries to argue that these policy changes institutionalized a hostile context for undocumented residents, establishing a local deportation regime.

\section{THE BOUNDARIES OF CITIZENSHIP FOR UNAUTHORIZED IMMIGRANTS}

The concept of citizenship is often used to describe one's formal legal status visà-vis the nation-state. Those with formal citizenship are presumed to "belong" to the nation-state and therefore are able to enjoy the rights that full membership in the national community entails. ${ }^{14}$ Understandings of citizenship as existing within the territorial boundaries of nation-states have evolved with the recognition that citizenship is more than legal standing in a politically bounded community. Modern conceptions of citizenship identify its four dimensions as legal status, rights, political participation, and notions of belonging. ${ }^{15}$ The substance and status of citizenship do not perfectly converge; formal citizenship does not guarantee full membership rights, nor does lack of citizenship imply an absence of rights.

Research on "citizenship" for noncitizens shows how immigrants who lack legal membership in the national community can accrue rights on the basis of their physical presence and/or deservingness. ${ }^{16}$ For example, in some locales, unauthorized immigrants have the right to vote in municipal elections and have access to municipal ID cards. These are examples of subnational or urban citizenship, a form of local membership that confers rights based on one's residence in an inclusive municipality or state. ${ }^{17}$ In contrast, the Deferred Action for Childhood Arrivals (DACA) program confers rights on the premise that undocumented young people are more "deserving" than the larger undocumented immigrant community because they arrived in the United States as children, some achieved educational mobility, and many consider themselves American. DACA allows eligible undocumented young adults to obtain temporary lawful presence, enabling recipients to receive a social security number, a work permit, and temporary protection from deportation. 
Citizenship regimes can also be understood as delineating the symbolic and social boundaries of membership. ${ }^{18}$ Symbolic boundaries are distinctions that actors use to justify people's inclusion or exclusion from group membership, whereas social boundaries confer unequal access to rights and opportunities on the basis of these symbolic boundaries. ${ }^{19}$ Boundaries shift when the lines that differentiate insiders and outsiders move in the direction of inclusion or exclusion. ${ }^{20}$

As this chapter shows, the presence of unauthorized Latino immigrants generated heated political debates in Tennessee. As the Latino immigrant population grew, they came to be constructed as a political problem, often by media shaping the meanings of local events. Compelled to "do something" in response to a growing backlash, city and state officials responded by stripping unauthorized immigrants of driver's licenses, forging new immigration enforcement partnerships, and considering a host of restrictive and exclusionary ordinances. In doing so, state and local legislators redrew the boundaries around local membership, drawing on powerful discourses about Latino immigrants' place as outsiders. Their choices set the stage for a local deportation regime that criminalized Latino immigrants and placed them at risk of deportation.

\section{SHIFTING DRIVER'S LICENSE ELIGIBILITY}

When Latino immigrants began arriving in Tennessee, they were eligible for Tennessee driver's licenses and identification cards, provided they could prove they were state residents. That changed in 1997, when Tennessee legislators changed state law to require that all applicants provide their social security numbers on license applications. The policy change emerged in response to the Personal Responsibility and Work Opportunity Reconciliation Act of 1996 (PRWORA), a federal welfare reform law. The PRWORA devolved responsibility for welfare programs to the states and made large categories of noncitizens ineligible for meanstested social problems. It also required states to collect social security numbers on license applications so that states could identify "deadbeat" parents who were not fulfilling child support obligations and could punish them by denying or revoking their licenses.

A social security number is a nine-digit number issued by the US government as a way to track individuals for social security and tax purposes. Citizens and noncitizens with permission to work in the United States are eligible for social security numbers, but not all noncitizens who live in the United States have one. When Tennessee legislators changed license eligibility standards to require a social security number, they effectively excluded all foreign-born residents without one from accessing state identity documents. At the time, this was not their intent. In fact, a newspaper article documenting the policy change made no mention of its effects on foreign-born residents. ${ }^{21}$ In the late 1990s, Latino immigrants 
were largely invisible to state legislators and government offices. ${ }^{22}$ The local antiimmigration laws that would emerge in the South were still a decade away.

A number of states changed eligibility for licenses in response to the PRWORA. Quickly, questions emerged about whether the federal government intended to exclude residents without social security numbers from obtaining driver's licenses and identification cards. As additional states sought clarification, the commissioner at the Office of Child Support Enforcement explained that the law was not intended to make getting a license contingent on having a social security number: "We interpret the statutory language ... of the Act to require that States have procedures which require an individual to furnish any social security number that he or she may have. . . The Act does not require that an individual have a social security number as a condition of receiving a license." ${ }^{23}$

In 2000, a group called the Coalition for a Safer Tennessee quietly began lobbying a few sympathetic state legislators to drop the social security number requirement on licenses. The coalition was composed of immigrant advocacy groups, religious groups, unions, employers, and public safety institutions. Rather than describe the policy change as a way to integrate a small number of unauthorized immigrants, the bill's sponsors emphasized that the law would protect all Tennesseans. Their pitch was simple: state residents are safer when drivers learn traffic laws, pass exams, and have access to car insurance. With little fanfare, Senator James Kyle, a Democrat from Memphis, and Representative Mike Turner, a Democrat from Nashville, introduced legislation to amend driver's license eligibility in February of 2001.

Some Republicans objected to the new legislation and attempted to add an amendment to require driver's license applicants to show proof of legal presence, but their attempts failed. At the time, public safety for all state motorists superseded immigrant exclusion, and legislators easily passed the bill to make unauthorized immigrants eligible for driver's licenses in April 2001. The local paper announced that legislators were putting "motorists' safety over [the] legal status of immigrants." ${ }^{24}$ Quoted about the policy change in the article, Representative Mike Turner (D-Old Hickory) said, "I don't know of any organizations except the Klan that's against this bill." ${ }^{25}$ The bill, which was signed into law in May 2001, amended the Tennessee Code to require applicants to provide a social security number "if the applicant has been issued a social security number" but allowed applicants who did not have a social security number to complete an affidavit stating that fact. ${ }^{26}$ This new state law was a de facto acknowledgment that unauthorized immigrants were part of Tennessee's populace. Expanded eligibility for driver's licenses and IDs shifted the boundaries of state membership, resulting in a form of "local citizenship" for unauthorized Latinos. With a driver's license, unauthorized residents had the freedom to drive without breaking the law and could identify themselves to state and government agencies. 
The number of residents in Tennessee without social security numbers had grown between 1997 and 2001. Within days of the policy change, the Tennessean reported that "legal and illegal immigrants" were "flooding driver's license testing stations." ${ }^{27}$ In the first few months of expanded eligibility, the Tennessee Department of Safety issued almost thirty thousand licenses to noncitizens, the vast majority of whom were unauthorized Latino residents. ${ }^{28}$ Government offices were overwhelmed and unprepared for the surge of new applicants, and few testing centers had bilingual employees. Newspaper stories documented chaos at testing centers, describing native-born residents who were angry about waiting in line for eight hours "behind people who couldn't understand the state workers' instructions." 29

Legislators who supported unauthorized immigrants' access to driver's licenses framed their support in terms of public safety, but after $9 / 11$ the meaning of public safety changed. Lawmakers worried about the freedom of movement that ID cards provided to noncitizen residents. Others believed that issuing driver's licenses made Tennessee a "magnet" for unauthorized immigrants. In reality, unauthorized immigrants composed a very small percentage of all drivers' licenses issued each year. In 2003, for example, the Tennessee Department of Safety issued approximately 1.4 million driver's licenses; fewer than 2 percent were issued to applicants without a social security number. ${ }^{30}$

Attempts to push unauthorized immigrants outside the boundaries of membership began immediately, as state legislators who opposed the new law began working to repeal it. They introduced over fifteen repeal bills between 2001 and 2004. These various bills provide insight into how state legislators draw membership boundaries, as some repeal bills were veiled attempts to eliminate only some immigrants' access to identification cards and driving privileges. For example, a failed 2002 bill sought to delimit eligibility for driver's licenses by requiring applicants to present documents establishing proof of identity and residency: a US birth certificate or passport, immigration documentation proving legal residence, or a Canadian birth certificate and driver's license. As the bill was written, Canadians would have been exempted from the requirement to have a social security number. A 2003 repeal bill was clearly designed to exclude Mexicans. This law would have banned consular identification cards as proof of identity for driver's license applicants; at the time, Mexico was the only country issuing identification cards to foreign nationals in Tennessee.

In 2004, after years of political wrangling, Tennessee passed a new "get tough" measure to restrict driver's licenses to US citizens and legal permanent residents. Everyone else-including unauthorized immigrants, international students, and temporary legal residents-would receive a new document called the "Certificate for Driving" (CFD). This legislation blurred the boundaries between unauthorized immigrants and legal immigrants without permanent residence by making both 
groups ineligible for standard Tennessee driver's licenses and IDs. ${ }^{31}$ Hailed as a compromise, the certificate conferred driving privileges but did not verify identity, thereby eliminating the state's role in legitimizing or institutionalizing immigrants' identities. Supporters hoped it would "slow the migration of undocumented or illegal immigrants" into the state. ${ }^{32}$

The CFD was a new document that did not exist anywhere else in the country. It created a tiered system of driving privileges, with significantly fewer protections for certificate holders compared to license recipients. For example, motorists had to renew the driving certificate yearly, whereas licenses were valid for five years. Car insurance companies did not cover certificate holders at the same rates or at all, making it challenging for immigrants to secure and afford insurance. Moreover, unlike driver's licenses, CFDs were not recognized in other states, restricting immigrants' freedom to travel.

The creation of the CFD also opened the door for frontline bureaucratic workers to police Latinos. Under the new policy, state employees inspected documents to determine whether prospective applicants were eligible for driver's licenses or CFDs. Although all foreign-born residents without citizenship or permanent residence were supposed to receive certificates, the CFD was understood as a document for Latinos. Acting on persistent stereotypes that undocumented immigrants were predominantly Latino, or that Latino residents were predominantly unauthorized, frontline bureaucrats were inordinately suspicious of residents who appeared to be of Latino descent. Legally present Latino immigrants reported having their legal documents-such as passports, birth certificates, social security cards, or green cards-seized by suspicious clerks who claimed the documents were fake. For example, a permanent legal resident of Nicaraguan descent had her passport, Florida driver's license, and green card confiscated after a state clerk accused her of trying to illegally obtain a driver's license. ${ }^{33}$ Clerks also attempted to seize birth certificates belonging to American citizens born in Puerto Rico, perhaps unaware that these Spanish-language documents constituted proof of citizenship. ${ }^{34}$ In addition, some legally present Latino immigrants reported being issued CFDs, even though they were eligible for driver's licenses.

Tennessee's CFD experiment was widely maligned. By 2006, reports that a department of safety employee sold driver's certificates to unqualified immigrants received almost daily attention on conservative talk radio. Additional investigations suggested that buses full of out-of-state residents were descending on the state to fraudulently obtain driver's certificates. ${ }^{35}$ In February 2006, the Tennessee Department of Safety announced it would stop issuing CFDs to unauthorized immigrants for the "security of Tennesseans." In an e-mail from the department of safety commissioner to state employees, the commissioner wrote: "Today, the Department of Safety is halting the issuance of Certificates for Driving to people who cannot prove they have legal presence in the U.S... The CFD program was a good 
idea, but there have been implementation issues. We need to give it a thorough review, to make sure we're doing what's best for Tennesseans.... The bottom line is this: immigration is essentially a federal issue. But ensuring the security of Tennesseans is a state issue, and it's one that both the Governor and I take very seriously." This decision "brightened" or hardened the boundaries between unauthorized immigrants and legal immigrants, as unauthorized immigrants lost all access to legal driving privileges in the state. Moreover, changes to federal law made it unlikely that driving privileges would ever be restored. In 2005, Congress passed the REAL ID Act to impose federal standards on state-issued photo identification cards. One of these standards was to make lawful immigration status a prerequisite for obtaining a driver's license or state ID card.

In 2007, the Department of Safety worked with Tennessee legislators to pass new driver's license legislation. The new law formally abolished CFDs and replaced them with temporary driver's licenses. Citizens and legal permanent residents would remain eligible for standard Tennessee driver's licenses, and temporary driver's licenses would be issued to legal immigrants who could prove they were legally authorized to be in the United States for at least a year. As written, the law excluded thousands of legally present foreign-born Tennessee residents from obtaining driving privileges, because not all legal immigrants are issued visas in multiyear segments. Foreign-born residents who could not prove that their legal presence was authorized for at least a year were ineligible for temporary driver's licenses until 2008, when legislators eliminated the one-year length of stay requirement for noncitizens.

\section{IMMIGRANT CRIMINALITY AND \\ THE 287(G) PROGRAM}

On June 8, 2006, at 11:30 a.m., a Mexican man named Gustavo Reyes García swerved into oncoming traffic and struck a silver Buick sedan headfirst. The driver and passenger in the silver Buick, a married couple from a Nashville suburb, died. The driver who had caused the accident emerged unscathed; his blood alcohol content was 0.34 percent, more than four times Tennessee's legal limit. Officers arrested Reyes García and booked him into the Davidson County Jail. This was not his first time in custody. His county arrest record dated back to 2001; since then, he had been arrested and convicted dozens of times on a variety of charges related to drunk driving.

When officials booked Reyes García into jail after the accident, they submitted his fingerprints to ICE's LESC in Vermont. This was a long-standing practice; the Davidson County Jail had been submitting arrestees' fingerprints to the LESC voluntarily since 2000 . Between 2000 and 2007 , the LESC requested that the county hold 151 arrestees on immigration detainers, but officials had never issued a 
detainer for Reyes García. After Reyes García was charged with a double homicide, ICE issued a detainer. This came as a shock to Davidson County's sheriff, Daron Hall, who explained their long-standing practice of sending information to the LESC:

The person, Reyes Garcia . . . his data was sent every time electronically. It was checked, supposedly, or at least received by the ICE office in Vermont. They sent notification back to us they received it, and he was cleared to be released. On this thirteenth or fourteenth arrest for the double homicide, it was the same process, except this time they said, "Don't let him go. He's a bad guy. He's been all over the board. He's illegally here." . . But we had him three months before this, same data, same system, and they said let him go.

Public outrage was swift as a number of news stories documented Reyes García's long arrest history and undocumented status. Sheriff Hall remembers the swell of media attention: "The first day, the story said two people were killed tragically in a head-on collision by a drunk driver. The next day, the headline said the drunk driver was illegally in the country. That got everybody else fired up. The third day, it was "illegally here, in the jail fourteen times, sheriff let him go," Sheriff Hall said.

According to media scholars, how stories are framed determines whether the public views them as problematic. ${ }^{36}$ Rather than critique Tennessee's lax punishments for repeat DUI offenders, stories made Reyes García's immigration status the dominant frame for his case. After the accident, print, radio, and television media outlets around the country covered the Reyes García story for weeks. A local headline announced, "ICE Overrun by Number of Illegal Aliens." ${ }^{37}$ Soon people linked Reyes García’s drunk driving offense to the earlier political fights about driver's licenses for unauthorized residents. Conservative talk radio host Phil Valentine served as the leading voice of the nativist backlash. Valentine appeared on Fox's O'Reilly Factor, describing the accident as "completely preventable" and calling for those who had supported driver's licenses for unauthorized immigrants to "explain themselves to the family of these people who died." ${ }^{38}$ Not to be outdone, television personality Bill O’Reilly described the accident as "a failure of Davidson County justice." ${ }^{39}$ Thus Reyes García’s drunk driving offense turned into an indictment of local officials' supposedly permissive attitudes toward unauthorized immigrants.

After the media reframed the story around the problem of immigrant criminality, local officials scrambled to account for their "failure" to keep the city safe. The sheriff and district attorney vowed to get answers from ICE officials. Sheriff Hall explained:

It took a couple of weeks of phone calls from the district attorney and myself to figure out what in the heck happened in the federal ICE office. Eventually, we got a midlevel 
person in the ICE office who told us that they no longer have the resources to check everybody. They only check people who commit aggravated felonies, which really are murders and rapes. Not because they want to, but because they don't have the resources. So they were telling us that all these people we'd been sending them, they hadn't been checking anyway.

By that time, several counties were participating in the federal government's 287(g) program, including Mecklenburg County, North Carolina. Incidentally, Sheriff Hall knew the sheriff of Mecklenburg County and called him for information about how to apply to the program. Sheriff Hall drafted a letter to the DHS in August 2006 to request immigration enforcement authority. Sheriff Hall indicated that he had been in contact with the local ICE agent in charge, local law enforcement officials, and their US congressman to pursue the program. Hall believed the $287(\mathrm{~g})$ program would allow him to identify "criminal illegal" aliens who posed a risk to citizens of Davidson County.

On September 5, 2006, the county sheriff, the police chief, and the district attorney held a joint press conference announcing "sweeping changes" to "deal with criminal illegal immigrants" in the city. ${ }^{\circ}$ Press releases issued by the sheriff's office and police department made clear that the sheriff was speaking for the police chief and the district attorney at the press conference. Their joint statement read as follows:

During 2006, several very serious cases involving criminal illegal immigrants in Nashville prompted the three of us to begin formulating plans to better protect the citizens of Davidson County. Recognizing that no plan or program is perfect, the 287(g) option appears to be well suited for Nashville and we immediately began making further inquiries. ... While Nashville is doing more than most cities by routinely checking foreign-born arrestees against an ICE database, it is clear that we can make our processes even stronger, but the federal government must grant our request. The three of us agree that the process we propose is in the best interest of everyone, including the law-abiding immigrant population.... It is important for us to emphasize that this program will affect only those illegal immigrants who have a blatant disregard for laws in Davidson County. If you are in this country illegally and commit a crime, we will process you under the federal authority given to us through $287(\mathrm{~g}){ }^{41}$

As this statement makes clear, Davidson County law enforcement officials decided to pursue immigration enforcement authority in response to several highprofile crimes with undocumented immigrant assailants. Officials used the crimes of a small number of undocumented offenders to suggest that the larger undocumented immigrant population might contain criminals in waiting. Their statement linked "illegal immigrants" and crime, suggesting that more robust immigration enforcement was necessary to protect Davidson County citizens. By implementing the $287(\mathrm{~g})$ program, Davidson County officials transformed the discourse about immigrant criminality from a symbolic boundary to a social one. 
Racial politics is central to understanding the implementation of the $287(\mathrm{~g})$ program. To justify their draconian measures, lawmakers invoked what anthropologist Leo Chavez calls the "Latino threat narrative," discourses that portray Latinos as an invading force that endangers US citizens. ${ }^{42}$ While crimes committed by citizens are often invisible, crimes with citizen victims and undocumented immigrant perpetrators receive disproportionate attention. This occurs because discourses linking immigrants to crime are influenced, not by crime rates, but by the perception that any crime committed by an undocumented immigrant is unacceptable. ${ }^{43}$ Crimes in which the suspected assailant is unauthorized are considered extraneous crimes, or crimes that would not have been committed with stricter immigration regulations. ${ }^{44}$ This framing demands that local authorities respond to "immigrant criminality" by "doing something" to protect residents. For example, sociologist Jamie Longazel argues that Hazleton's anti-immigration law emerged after legislators connected Latino assailants to white victimization. ${ }^{45}$ Comparing local responses to two homicides allegedly committed by (unauthorized) Latino perpetrators in Hazleton, Longazel shows that the homicide with the white victim engendered outrage and panic, while the homicide with the nonwhite victim went largely unnoticed. Even though crime in Hazleton had been falling for several years, lawmakers insisted the anti-immigrant ordinance was necessary to combat a crime wave that was not actually happening. ${ }^{46}$

It is worth noting that sheriff's departments are more likely than police departments to report cooperating with immigration enforcement authorities. ${ }^{47}$ For example, virtually all $287(\mathrm{~g})$ programs were implemented by local sheriff's offices, which have different responsibilities and accountability structures than police departments. Sheriffs are locally elected officials and accountable to voters, whereas police chiefs are appointed and accountable to local government. ${ }^{48}$ Generally, police departments serve particular cities and towns, whereas sheriff's departments have jurisdiction over counties. In some places, including Nashville, the sheriff's office does not provide direct law enforcement services but administers the county's correctional facilities. However, in jurisdictions where both police departments and sheriff's offices provide law enforcement services, police departments generally handle calls and enforcement inside city limits, while sheriff's offices tend to patrol sparsely populated unincorporated county areas. A national survey of police chiefs and sheriffs throughout the country revealed that sheriffs were twice as likely as police chiefs to report that federal officials influenced their agency's immigration enforcement practices; in addition, police chiefs were more likely than sheriffs to express concern about the department's standing and reputation in immigrant communities. ${ }^{49}$

In January 2007, the DHS approved Davidson County's participation in the $287(\mathrm{~g})$ program. Immediately, immigrant organizers and advocates expressed concerns that the sheriff might use the program to initiate mass deportations. "We 
can't emphasize enough that if this program is implemented in a way where someone could be deported simply for driving without a license, then that's not the kind of program that was pitched at the outset," David Lubell, president of the Tennessee Immigrant and Refugee Rights Coalition, told the Nashville City Paper. ${ }^{50}$ The Nashville City Paper quoted Sheriff Hall as agreeing with members of the Sheriff's Advisory Council (SAC) and stating that local officers should not detain suspected unauthorized immigrants who posed no threat to the public. "The purpose of this [program] is not to automatically deport people. It's to avoid ignoring them," said Sheriff Hall..$^{51}$

When the Davidson County Sheriff's Office (DCSO) signed the memorandum of understanding to participate in $287(\mathrm{~g})$ program, the county did not decide to run a targeted enforcement model, as members of the immigrant advocacy community had hoped. Instead, the county designed their program like Mecklenburg County's, screening every foreign-born person arrested in Davidson County by local police for immigration violations. This decision ensured that the program would ensnare thousands of low-level misdemeanor violators.

\section{ENGLISH ONLY}

Amid debates about the $287(\mathrm{~g})$ program, another political battle was being waged over a symbolic ordinance to declare English the official language of the city of Nashville. In January 2007, the Nashville Metro Council considered several antiimmigrant ordinances. ${ }^{2}$ Several of the bills under consideration were modeled after bills in Hazleton, Pennsylvania. While the bills to punish businesses for hiring unauthorized immigrants and landlords for renting to them were deferred indefinitely, the council passed an English-only ordinance, declaring English the city's official language. Nashville mayor Bill Purcell vetoed the ordinance the same month that Davidson County was approved to participate in the $287(\mathrm{~g})$ program, saying that it conflicted with the city's values. "This ordinance does not reflect who we are in Nashville," said Mayor Purcell, arguing that the ordinance would make Nashville "less safe, less friendly, and less successful." ${ }_{53}$

By the summer of 2008 , the $287(\mathrm{~g})$ program had been running in the county jail for over a year, but frustration about Latino immigration continued to simmer. Councilman Eric Crafton tried again to make Nashville an English-only city, this time by making the issue a ballot amendment. Although Crafton collected the ten thousand required signatures to get the law on the ballot of the 2008 general election, the Davidson County Election Commission declined to put the law to a vote. Nashville's Metro Charter allows for only one voter-led amendment each two years, and the Metro Department of Law determined that Election Day came three days too soon, one year and 362 days after the last voter-led amendment. The councilman sued the election commission, but the English-only bill did not make it on the ballot for the November 2008 elections. Undeterred, Crafton started the 
petition process again, collecting over five thousand signatures to force a special election on the bill. Crafton's efforts were payrolled by a national group that calls itself ProEnglish, whose founder is behind several organizations that the Southern Poverty Law Center counts on their list of hate groups. ${ }^{54}$

As a new immigrant destination, Nashville has no recallable history of immigrant sentiment through which local residents can make sense of new arrivals. As residents try to understand new demographic diversity, they rely on available discourses and frames about Latino immigrants. The notion that Latinos cannot or will not learn English is a recurrent theme in immigrant threat narratives. ${ }^{55}$ Indeed, supporters of the English-only charter amendment saw it as a way to reclaim and reassert Nashville's status as an "American city." Like other pieces of anti-immigrant legislation being considered across the country, debates about Englishonly legislation reflected anxiety over the meaning of American identity.56 To white residents of diversifying neighborhoods, Latino immigrants represented the loss of their idealized communities and encroached on their sense of belonging. ${ }^{57}$

Supporters of English Only believed that Latino immigrants should conform to their linguistic expectations. Their campaign's website stated: "By expecting immigrants to learn English we encourage them to improve their skills and earning power, pursue the American dream and become fully self-sufficient participants in our democracy-just as our ancestors set in motion for us." ${ }^{58}$ While this statement appears to be race-neutral, narratives that draw on America's immigrant past trigger comparisons between the "successful" incorporation of European immigrants across generations and the current standing of Latino newcomers and their children. These narratives are frequently deployed to rationalize exclusions against contemporary immigrants, who are seen as undesirable. ${ }^{59}$

Opponents of the English language charter amendment mobilized to oppose the bill under the banner of "Nashville for All of Us" (N4AOU). N4AOU stressed that the law was not a referendum on immigration and would tarnish the city's reputation as friendly to international businesses and tourists. The local political establishment considered the ordinance so important that the newly elected mayor's senior adviser took a two-month leave of absence from his job with the city to run the campaign against English Only. Opponents to English Only included major local corporations, religious organizations, business groups, over two hundred religious and spiritual leaders, and the Nashville mayor and Tennessee state governor.

Despite a carefully orchestrated campaign, members of $\mathrm{N}_{4} \mathrm{AOU}$ feared they might lose the vote. At a December campaign meeting, phone bankers told stories about calling voters who supported the amendment because they believed Nashville was losing its character. As the election approached, news coverage speculated about what bilingual city services might be eliminated if English Only became the law. 
On voting day, Governor Bredesen and the newly elected Nashville mayor, Karl Dean, cast their votes against English Only at side-by-side voting machines. It was the largest turnout for a special election in a decade. The night of the election, $\mathrm{N}_{4} \mathrm{AOU}$ members gathered for a party at Lowe's Hotel in West Nashville. Cheers erupted as they learned Crafton's English Only referendum had suffered a sound defeat. Amid loud cheers and whistles, a campaign member yelled loudly, "Today English Only, tomorrow 287(g)!"

Ultimately, businesses and political leaders lined up to reject English Only, arguing that the ordinance tarnished Nashville's reputation as a welcoming city for all visitors. While the frame of a welcoming Nashville won out against the symbolic anti-immigrant ordinance, public figures who mobilized against English Only declined to speak out publicly against the $287(\mathrm{~g})$ program because it was understood as targeting "criminal aliens."

\section{SETTING UP $287(G)$ IN THE DAVIDSON COUNTY JAIL}

DCSO employees lined up for the opportunity to rid Davison County of "criminal aliens." Over two hundred people, one-fourth of all DCSO employees, applied for sixteen positions to participate in the $287(\mathrm{~g})$ program. The sheriff and his staff enthusiastically endorsed picking the "best" employees in the organization and tried to weed out those who wanted to do the job for the "wrong" reasons. They implied that wanting to deport "illegal aliens" for breaking the law was fine, but openly expressing hostility or antagonism toward immigrants was not.

Prospective applicants coveted these positions for a variety of reasons. Many believed that the program would enhance public safety. Some believed the job represented an opportunity for upward mobility and professional development, which was uncommon in the sheriff's office. Others were motivated by the program's novelty, which allowed them to perform tasks that were completely unlike their previous ones. Chad, a DCSO employee who was picked to participate in $287(\mathrm{~g})$, explained why the program was so exciting for applicants: "It was something new, it was something that it was kind of in the news, a lot of people were aware of it and wanted to be part of something different. The federal training, I think was kind of intriguing to people to basically . . . to say we're designated ICE officers. We have IDs that say I'm an immigration officer." He opened a black leather wallet and proudly displayed his badge.

Officers endured four weeks of training that all described as challenging. Michael, a former booking officer, described walking into the classroom on the first day of training and briefly regretting his decision to participate in the program. "We got there, we saw all these books piled up on immigration law and everything, and I thought, 'What have I gotten myself into?'” he explained, chuckling. Because their positions were so highly coveted and officers received special 
training, they believed their designation as immigration officers represented a professional achievement. "Look at the picture on the wall," Ronnie said, pointing to the snapshot of his smiling coworkers. "All these individuals, they were the ones who started this and no one else. Whether they come to replace [us] or not, they can't say they were at ground level when it got started. . . My number one reason [for applying] was I kind of felt like it was cutting-edge law enforcement. You know, it was kind of what was coming. You could see it coming across the board in the entire nation."

Before the federal government had the capacity to automate immigration screenings through biometric databases, federal immigration officers interviewed suspected immigration violators in jails through ICE's Criminal Alien Program. Without the time or resources to check everyone, federal officers used shortcuts, interviewing Spanish speakers with Latino surnames. When the $287(\mathrm{~g})$ program started in Davidson County, an initial concern was how officers would select immigrants for screening without relying on racial markers of "illegality." The jail addressed these by taking steps to eliminate discretion. Booking officers relied on information from the police officer's arrest report (which indicated each arrestee's place of birth) to determine whom to flag for questioning. A supervisor explained how this worked:

Everybody who is foreign-born gets the [red] stamp on their paperwork to go to ICE. They're not in the decision making, they're just basically filtering the paperwork to us. Our people are looking at the police report and looking at the place of birth, so if it says Guatemala, then they put in Guatemala, and it says foreign-born so that goes to us. So, they're not really-the police aren't checking a box, they're just putting their place of birth, and we kind of take that information and go from there.

Since all foreign-born arrestees were flagged for immigration screenings, all foreign-born inmates were put on an ICE investigative hold until cross-deputized officers determined their immigration status. Officers used a database from the DHS to determine if the arrestee was legally present, was a US citizen, or had had previous contact with the immigration bureaucracy. When the officer determined that the arrestee was legally present, the officer removed the investigative hold. If the officer believed the arrestee was removable, the officer would conduct an administrative interview to collect additional information.

During interviews, officers referred to an ICE handout that outlined a series of questions officers might ask to determine the arrestee's removability. While this interview was part of the investigation of a person's status, it was characterized as a mundane administrative task. The ICE official who supervised Davidson County's $287(\mathrm{~g})$ program explained the interview as follows:

It's not an interrogation by any means, it's almost like general information, almost like if you were going to get booked and a police officer was to ask you the same 
information, almost. We just get a little more of the information for immigration purposes.... And honestly, most people are very nice and forthright and say I swam the Rio Grande or I paid a coyote or I came through Laredo, you know.

When the interview revealed that the arrestee was removable, deputized immigration officers turned the investigative ICE hold into a regular ICE hold, or immigration detainer. This was a signal that the inmate would not be released from custody but would be transferred directly to federal authorities at the conclusion of his or her criminal case.

Next, DCSO officers compiled various documents in one file associated with the arrestee's assigned alien registration number (also known as an A number). The DHS assigned an A number to all noncitizens who interacted with the immigration bureaucracy, whether they were seeking citizenship, applying for asylum, or in removal proceedings. Once officers prepared the various documents required to pursue a person's deportation, immigration officers handed off the A file to their ICE supervisor, a federal DHS employee, who was stationed at the jail. The ICE agent signed off on the document, ensuring that the arrestee would be deposited in the immigration enforcement bureaucracy, rather than released from custody after his or her criminal case was resolved.

Since the DCSO was approved to house ICE inmates through an intergovernmental service agreement, this shift in custody did not necessarily involve a transfer out of the county jail and into an ICE detention facility. An immigrant arrestee could go from DCSO custody to ICE custody while never leaving his or her cell. The county absorbed the costs of incarcerating people who were in DCSO custody but received sixty-three dollars for each day they held someone for ICE. Two to three times a week, ICE picked up and took physical custody of detainees from the Davidson County Jail.

\section{CONTESTING THE BOUNDARIES OF IMMIGRANT CRIMINALITY}

While officials used rhetoric about immigrant criminality to justify the $287(\mathrm{~g})$ program's adoption, local officials designed the program to ensnare as many unauthorized immigrants as possible. In Nashville, as was the case across the South, traffic enforcement and misdemeanor violations were central to the $287 \mathrm{~g}$ ) program's expansive reach. The program's design was a blow to immigrant advocates who insisted that the sheriff had implied he would target only offenders convicted of serious crimes. Throughout the program's tenure, this would be a central disagreement between the sheriff and critics of his enforcement policies.

Before the $287(\mathrm{~g})$ program's implementation, Sheriff Hall assembled a group of people to form a Sheriff's Advisory Council (SAC). The SAC was composed of 
representatives from the DCSO, the police department, the public defender's office, and the district attorney's office, as well as academics, immigrant advocates, and private attorneys. The SAC convened for its first meeting in December of 2006. Not surprisingly, immigrant advocates were cautious about any program that expanded immigration enforcement by local authorities. According to SAC participants who were involved in the earliest conversations about the program, the sheriff suggested the program would target criminal offenders. For example, the director of a local immigrant rights organization remembered the first SAC meeting as follows:

At this point, the program was still hypothetical. We thought, what is one more tool to identify people who are really dangerous? It was a pretty good little road show the sheriff put on.... What he said was, "I'm doing the program for this reason. The focus of the program is for this reason, so good and hardworking neighbors and friends don't have anything to worry about with $287(\mathrm{~g})$."

An immigration attorney described Sheriff Hall's initial descriptions similarly:

The way he described it to me is that it would only be applicable to dangerous criminals - that is, people who were undesirable, people who had committed a serious crime or crime of violence that we didn't need remaining here in Nashville. And, so he said, given those parameters, would you be interested in serving on the Sheriff's Advisory Committee for this 287 (g) program? I said yes. My thoughts were that it was a meritorious program. If we could identify those people that were causing violence and committing serious crimes in this community, and get rid of them, then it would help allay community concerns about undocumented immigrants in general and might help cast the rest of the immigrant population in a better light.

Another member of the SAC described his understanding of the program as follows:

I definitely am of the opinion that the sheriff promoted this program as a program that really was the result of certain major crimes or certain proportionate incidents in the community. ... I'll say to my dying day that the sheriff promoted this program as one that deals with dangerous and violent offenders-which you know what? I didn't initially have any trouble with, and I still don't, I still don't to this day. If $287(\mathrm{~g})$ is narrowly tailored to deal with major offenses, criminal offenses, and I know that the original intent was for things such as drug trafficking, human smuggling, major offenses, I have no problem with 287(g) because I don't want those folks in our community either. The problem is ... the net that has been cast has been much broader than the program was ever promoted as.

Ultimately, these disagreements stemmed from the stark differences in each group's understanding of immigrant criminality. Most unauthorized immigrants who ended up in DCSO custody were arrested for misdemeanor driving offenses 
and booked because they did not have valid identification. This did not happen because immigrant residents were inherently "criminal"; it happened because legislators changed laws and police enforced them. Still, Davidson County officials used these misdemeanor arrests as proof of unauthorized immigrants' criminality. For example, early in the program the sheriff told a local paper, "I wouldn't want to detain people just because they were in the country illegally. But if you're violating the law locally, criminally, and you're an undocumented person we don't believe we should just release you and ignore your status. And if you're a risk to public safety, you should be detained." ${ }^{\circ}$ This statement suggests that to local officials a misdemeanor arrest was proof of criminality, even if that arrest never resulted in conviction. To them, arrested immigrants deserved to be processed through the $287(\mathrm{~g})$ program.

The $287(\mathrm{~g})$ program represented a substantial escalation in immigration enforcement because it transformed the Davidson County Jail from a site where ICE occasionally issued detainers to pick up noncitizens to one in which DCSO employees issued detainers en masse. This model reflected local preferences, as the DHS gave local law enforcement agencies wide latitude to use the $287(\mathrm{~g})$ program to suit their own preferences and priorities. ${ }^{61}$ Some law enforcement agencies used this flexibility to design targeted $287(\mathrm{~g})$ programs. For example, the Durham Police Department utilized the 287 (g) program as a tool for "gang suppression" policing, investigating the immigration status of individuals arrested for felony weapons, narcotics, and property offenses. In contrast, the Wake County Sheriff's Office, with the support of the county government, used the $287(\mathrm{~g})$ program to conduct expansive immigration status checks for all immigrants housed in the county jail, arrested on any charge. While both agencies directly enforced immigration laws, Durham's task force program resulted in the deportation of several dozen people, whereas Wake County's jail enforcement model resulted in the deportation of several thousand. ${ }^{62}$

The policy choices outlined in this chapter are crucial for understanding Latino immigrants' marginalization in Davidson County and the region's changing context of reception for immigrant residents. Scholar Lisa Marie Cacho argues that legislators do extensive ideological work to construct imaginary boundaries around deserving and undeserving members of the public. ${ }^{63}$ Debates about driver's licenses, $287(\mathrm{~g})$, and English-only laws bring this boundary making into sharp relief. As this chapter shows, the presence of unauthorized Latino immigrants generated heated political debates in Tennessee. Drawing on discourses of immigrant criminality, city and state officials made unauthorized immigrants ineligible for driver's licenses and identification cards and forged new immigration enforcement policies. These decisions turned Nashville's streets and neighborhoods-the spaces of everyday life-into zones of immigration policing. 
Driving is crucial for living and working in Nashville; the inability to drive legally restricts immigrants' freedom of movement and contributes to a sense of insecurity. According to Mathew Coleman and Angela Stuesse, programs like 287(g) "have resulted in a climate of terror, in which immigrants live in fear they may be separated from their families every time they step outside their homes." ${ }^{14}$ Cecilia Menjívar and Leisy Abrego similarly argue that the criminalization of immigrants at the federal, state, and local levels creates fear, anguish, and social suffering related to immigrants' vulnerability to deportation. ${ }^{65}$

It is not an accident that excluding unauthorized immigrants from driver's licenses and IDs makes immigrants more arrestable but not less employable. Punishing "illegality" by socially and symbolically excluding unauthorized immigrants from membership is perfectly compatible with integrating undocumented workers in low-wage labor markets. Deporting everyone is neither practical nor possible. Keeping immigrants as outsiders while they remain inside the boundaries of the state serves a productive function in that it helps maintain a compliant and exploitable workforce. ${ }^{66}$ In this way, immigration enforcement is not only about banishing people through deportation but about controlling and disciplining deportable immigrants in the nation's interior.

In the next chapters, I move beyond a description of the criminalization of immigration law to consider the on-the-ground processes that criminalize Latinos and channel them into the immigration enforcement system. Frontline bureaucratic actors, particularly local police, play a crucial role in Latino immigrant removal. The next two chapters examine how the Metropolitan Nashville Police Department and its officers dealt with the challenge of policing Latino immigrants. I highlight the department's extraordinary efforts, and sometimes failed attempts, to improve the department's standing in the Latino community. I also highlight the dilemmas that officers experienced as they attempted to balance the bureaucratic priorities, department policy, and their own ideas about what constituted good policing. 